HARRIS, K. (1958). J. gen. Microbiol. 19, 55-64

\title{
A Study of Mallomonas insignis and Mallomonas akrokomos
}

\author{
BY KATHARINE HARRIS \\ Botany Department, University of Reading
}

\begin{abstract}
SUMMARY: Two species of Mallomonas (Chrysophyceae), M. insignis Penard and $M$. akrokomos Pascher ex Ruttner manuscript were investigated with optical and with electron microscopes. Carbon replicas have now made it possible to learn how the scales fit together in the armour and in particular how the tail, in each species, is constructed. Direct electron micrographs in conjunction with replicas have given much additional information about the scales. Developmental stages of $M$. insignis have been noted.
\end{abstract}

This paper describes two species of Mallomonas both of which are widely distributed in Europe. Both are common in southern England (Berkshire and Hampshire) and, in certain seasons, may become abundant. Both are easily recognizable with the low-power microscope and both prove to be exceedingly interesting when examined with the electron microscope, which clarifies several features that are puzzling with the optical microscope and reveals a wealth of unsuspected detail. Mallomonas akrokomos Pascher ex Ruttner manuscript and $M$. insignis Penard have nothing in common except that the posterior end of each is drawn out into a slender tail, but this tail is differently constructed in the two. Each species stands apart in the genus, showing no close affinity with any other in scale structure, while most of the numerous species of Mallomonas fall into natural groups with similar types of scale.

\section{METHODS}

The methods used in the examination of the Mallomonas spp. with optical and electron microscopes were described by Harris (1953) and Harris \& Bradley (1957). Both direct and replica electron micrographs were used throughout the present work since they show different aspects of the scales. The direct electron micrograph shows the variation in the electron density of the scale substance, while the shadowed replica only shows the form of the exposed surface.

Free-hand drawings were made from living and dead material and annotated with dimensions; the final drawings were constructed from these. The development was studied from samples taken from two localities which both contained very numerous individuals.

\section{MALLOMONAS INSIGNIS}

History. Mallomonas insignis was first described by Penard (1919) in a very careful and detailed paper; his description was discussed in Conrad's monograph (1933) and briefly summarized by Huber-Pestalozzi (1941); 
certain aspects were further elucidated by Bourrelly (1951). While I am in agreement with much that has been published by these authors about this organism I do not accept all their interpretations and shall discuss these differences later.

Occurrence. Mallomonas insignis has been found in ponds, ditches and flooded fields on agricultural land and also in pools and lakes on acid peat. It may be found from time to time between late November and April but, like all species of Mallomonas, it tends to be both brief and erratic in its occurrence. In suitable seasons, especially when winter floods begin to dry up, it may be found in very large numbers, but in some seasons it is only rarely seen. Cysts have been found in April.

Description of Mallomonas insignis as seen with the optical microscope

Mallomonas insignis is a long spindle-shaped organism bluntly pointed in front and tapering to a tail of varying length at the rear. The flagellum varies from about one-quarter to three-quarters of the body length. A large conspicuous nucleus is present at the anterior end and there is frequently a leucosyn body behind this. The form of the chromatophore is usually obscured by the strongly refractive corrugations of the armour, but whenever $I$ have been able to see it, it has been single and divided into two lobes by a cleft at the anterior and posterior ends. The anterior cleft is always short and usually conspicuous. The posterior cleft may be short as in Fig. 7 or may be so long that it nearly meets the anterior cleft, as in Fig. 8. Contractile vacuoles are usually present in the posterior cleft. Sometimes, presumably when the nucleus is about to divide, the chromatophore shows several lobes and its structure is obscure. The surface of the cell is covered with a rather rigid armour of thick concave silica scales which are conspicuous in the living cell. The anterior scales bear short prominent spines, the middle scales are spineless, while the scales on the tail are quite small and bear slender spines which are not always visible on the living organism. A fine strand of protoplasm runs down the whole length of the tail. $M$. insignis is sluggish, sometimes swimming rather slowly but often remaining still for long periods with a gently waving flagellum. Cysts (Fig. 13) are nearly spherical, smooth with a posterior pore which often protrudes slightly, size $14-28 \mu \times 25-30 \mu$.

\section{Development}

Figures 1, 2, 4,-6 and 9-12 illustrate stages recognized in the development of Mallomonas insignis. The anterior part of the cell in all organisms examined had scales resembling those of a mature cell, but the middle part was often only lightly armoured while the tail was not developed or was short and feebly armoured. I have not been able to see an individual without a tail develop a fully-formed tail, but I have often watched the protoplasm extrude through the posterior end as though to form a tail. Since this extrusion was limited and the contractile vacuole and flagellum continued to function normally, I concluded that the extrusion was part of normal development and not due to the cell being damaged or moribund. Figures 9 and 10 show a change. 

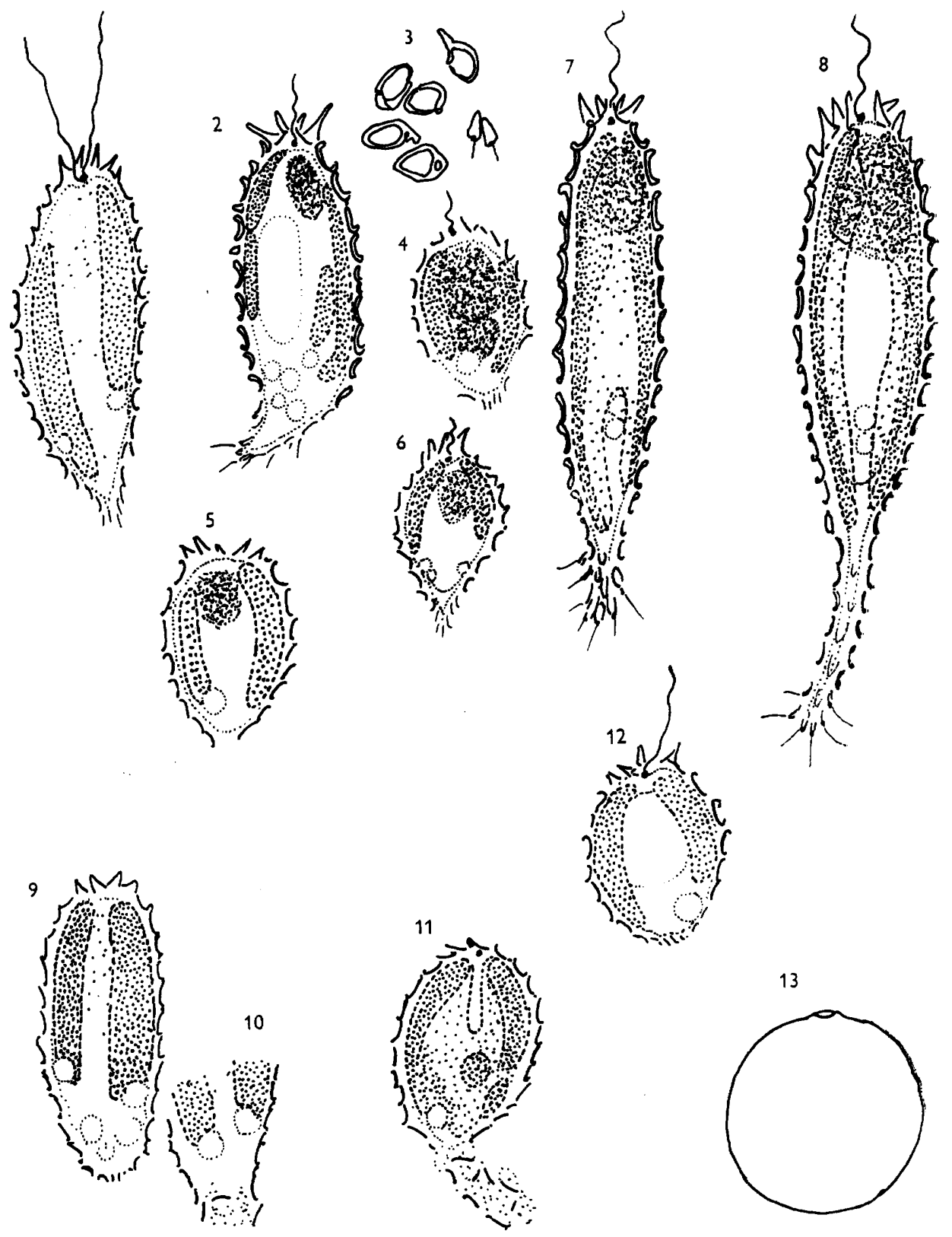

Figs. 1-13. Mallomonas insignis. All figures are $\times 1000$. 1. Dividing individual with two flagella, posterior end immature. 2. Individual showing four chromatophore lobes and numerous contractile vacuoles, posterior end immature. 3. Group of scales, two with spines from anterior end, three without spines from middle and two small ones with spines from tail. 4. Very early stage showing two nuclei, some scales peeling off, others missing, delicate parallel scales where tail will develop. 5. Very early stage without flagellum showing a gap in the armour where the tail will develop. 6. Very early stage with delicate immature tail already formed. 7. Mature individual with short tail showing a short posterior cleft in the chromatophore. 8. Mature individual with long tail showing very long posterior cleft in the chromatophore. 9. Early stage without flagellum, no tail present but group of parallel scales at rear, numerous contractile vacuoles present in rear part of cell. 10. Rear end of same individual some minutes later showing cytoplasm extruding. 11. Early stage showing long protoplasmic extrusion at rear. 12. Very early stage showing delicate parallel scales at rear. 13. Cyst. 
taking $c .10 \mathrm{~min}$; ; in the rear end of a single cell, which I watched. Figure 11 shows a cell with an unusually long extrusion of protoplasm which showed no change and no signs of dying during $c .10 \mathrm{~min}$. while I watched it.

\section{Description of Mallomonas insignis as seen with the electron microscope}

\section{(Plates 1 and 2)}

The whole cell is seen to be covered with scales which are elaborately sculptured on the outer side, flat or slightly concave and relatively smooth on the inner. They vary progressively from the anterior to the posterior end of the organism but the same basic pattern can be traced through all. No dome and no bristles are present but a shield and flange can be distinguished. The shield is bounded on the free side by a broad thickened ridge usually covered by papillae. A hollow spine arises from this ridge in some scales. There is a raised fold where the shield joins the flange, and in many scales this is somewhat hooded, overhanging the shield. The central area of the shield is thin and may show a few groups of papillae. The part of the flange joining the shield is fairly thin and bounded by a thickened rim rising steeply and often hooded, while it slopes gradually towards the margin. Direct electronmicrographs of some scales (Pl. 1, fig. 6) show minute perforations over the whole scale, but in others these perforations are not apparent.

The extreme anterior scales are a little smaller than the succeeding scales and bear stout hollow spines, ridged at the base and bearing a characteristic bent tip (PI. 1, figs. 1, 2). The next scales have smaller spines (Pl. 2, fig. 7) and those following have no spine at all (Pl. 1, fig. 3; Pl. 2, fig. 8). After this there is not much change, except that the scales become slightly broader and rounder (Pl. 2, fig. 10) until the cell narrows towards the tail. Here the scales become a good deal smaller, asymmetrical and somewhat varied in detail (Pl. 1, figs. 5, 6; Pl. 2, fig. 14). Some of these have a short spine with a bent tip (Pl. 1, fig. 3). They are intermediate in shape and size between the scales in front and those of the tail. On the tail the scales are once again symmetrical, smaller, less heavily sculptured and differing in the shape of the sculpture from the forward scales. They have slender spines which vary in length and are longest at the end of the tail. The scales at the anterior end of the cell point forwards, those in the middle have their long axis across the cell while those on the tail overlap so that the free end, with the spine, points backwards. Pl. 1, fig. 4, shows a replica from about the middle of a cell in which the scale armour has not been disturbed. The scales lie in rows across the cell and are so placed that the flange is always hidden by the overlap of the neighbouring scales. At the top right-hand side, where a scale has broken away, a flange is visible. The scale arrangement is the same as in other species which have been studied, e.g. Mallomonas leboimii, $M$. lychenensis and $M$. coronata and others of the same groups (Harris \& Bradley, 1957). Each of these species has a flange varying in form and in breadth, and in each case it is covered by neighbouring scales in the unbroken armour. Although $M$. insignis stands apart from other species in the features it shows under the optical microscope, its 
scales are normally arranged. Plate 2 , fig. 11 , shows part of the tip of the tail with its scales overlapping so that the spines point backwards. The spines are of varying length.

\section{Discussion}

On the whole this account of Mallomonas insignis corroborates and amplifies Penard's description but my interpretation of the tail extremity differs from his. He says that the cytoplasm comes out at the end of the tail and forms a number of adhesive threads which serve to fix the cell to a substratum. These he shows in his figure, which is reproduced by Conrad (1933; fig. 22b) and by Huber-Pestalozzi (1941; taf. XXII, fig. 13I). Penard says that these filaments are silica threads coated with glutinous or mucilaginous material and that they move in currents of water. As we have seen these 'filaments' are slender spines, outgrowths of the scales.

The description of the chromatophore by previous authors, as two structures, rather than a single bilobed one differs from my interpretation. Bourrelly (1951) first demonstrated the bilobed structure of a Mallomonas chromataphore in $M$. coronata Perman and Vinnikova (syn. M. doignonii Bourrelly). Harris (1953) and Harris \& Bradley (1957) showed the same type of structure in a number of other species. Although the structure of the $M$. insignis chromatophore is particularly difficult to see, $I$ believe it to be of the same nature as those of other species.

Penard suggested that Mallomonas insignis might be merely a variety of M. pulcherimg Stokes (1888), at that time known only from America. (I have not been able to see Stokes's paper.) This species is now known also from Europe and the figures given by Stokes for the American specimens and by Conrad for the European ones, while they agree with each other, differ considerably from $M$. insignis. I think, therefore, that the two species have rightly been kept apart.

Mallomonas torulosa Kisselew (1931) must, I consider, be $M$. insignis. The drawing suggests $M$. insignis at a stage when its tail is not fully developed. No indication of the scales is given but its size, $81 \times 15 \mu$ is the same as that of M. insignis. M. mesolepis Skuja (Huber-Pestalozzi, 1941) is, I believe, a synonym of $M$. insignis. The size and appearance are that of $M$. insignis with a somewhat immature tail. The scales are rhomboidal rather than oval but, though the scales of $\boldsymbol{M}$. insignis are oval, the disposition of the thickening often makes them appear somewhat rhomboidal under the optical microscope and they certainly look rhomboidal when seen on the living organism.

\section{MALLOMONAS AKROKOMOS PASCHER EX RUTTNER MANUSCRIPT}

History. Mallomonas akrokomos was described by Ruttner in a manuscript which was first published by Pascher (1913). It is usually known as $M$. akrokomos Ruttner, but the correct name would seem to be that given above. It was later described by Swirenko (1924), Schiller (1926), Conrad (1927), Krieger (1930), Woloszynska (1939) and Nygaard (1949). Asmund (1956) was the first to study the isolated scales which she figured as seen with the optical 
and the electron microscope. Both Conrad (1933) and Huber-Pestalozzi (1941) published descriptions and figures and these are probably the most easily obtainable references. The descriptions of all these authors agree with each other on most points. A few varieties have been described and these will be discussed later.

Occurrence. Mallomonas akrokomos is by far the commonest species of Mallomonas in Hampshire and Berkshire. It occurs in a great variety of localities such as ponds, lakes, ditches and flood waters, both on acid peat and on agricultural land. I have found it in each month of the year except Septemper, but it is rare in July and August and certainly commonest in winter and early spring. Cysts have been found from December till April. It is a species which thrives in cold weather and may become abundant under ice. In spite of its commonness it is sporadic and one can rarely count on finding it at any given time or place. It has been reported from Austria, Germany, Belgium, Russia, Poland and Denmark, but only in cold weather, whereas in Britain though it is commonest in cold weather it also occurs in warm weather.

\section{Description of Mallomonas akrokomos as seen with the optical microscope}

The organism is spindle-shaped tapering to a slender tail which may be straight or bent; its length is $20-60 \mu$ or occasionally more, and the breadth 5-15 $\mu$. A group of bristles usually occurs at the anterior end of the cell; frequently eight bristles are present, four or five being long and four or three being short. The number of long bristles may, however, vary from three to six and the short ones from none to four. While I have seen individuals with no bristles at all or with long bristles only, I have not seen any with short bristles only. The bristles of the living organism are more or less curved especially when the individual is swimming and they may be directed forwards or outwards or some forwards and some outwards. The bristles of a dead or fixed individual appear straighter, but here also there is a good deal of variation. With the optical microscope the bristles look smooth. The long bristles vary from 19 to $35 \mu$ and the short ones from 8 to $15 \mu$. The flagellum is commonly half bodylength but may be considerably longer. The chromatophore is single, usually divided into two lobes by posterior and anterior clefts which nearly meet. There are often contractile vacuoles present in both posterior and anterior clefts. Sometimes no cleft is clearly visible and the division of the chromataphore seems to consist of a string of contractile vacuoles (Fig. 21). The lobes are usually obliquely placed and may be very unequal in size. The cytoplasm does not pass down the tail to its tip (Fig. 14). Movement is very fast. The cyst is oval and smooth, its pore may be surrounded by a narrow or broad rim or none at all, and may be posterior or anterior. I have seen cysts of both types in the same sample of water.

The scales as seen on the unbroken cell may, in some conditions, appear like small triangles, such as were described by Conrad. Isolated scales look like delicate oval or slightly pointed plates, and become narrower as they approach the tail. The bristle-bearing scales, which are at the extreme anterior end, are 
oval with a clearly visible dome. The tail itself is usually seen as a single rod, though occasionally two rods may be seen lying side by side.

I have many times watched Mallomonas akrokomos dividing. Division was longitudinal, starting with the flagellum and passing from the anterior to the posterior end of the cell. When it was complete the two daughter cells swam away from each other.

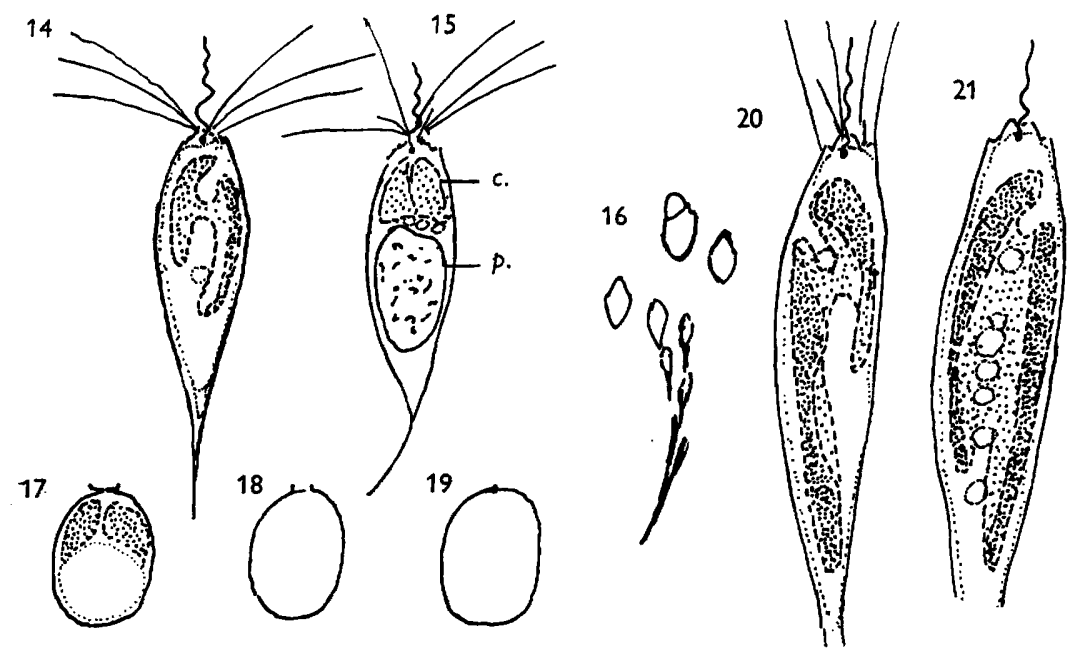

Figs, 14-21. Mallomonas akrokomos. Figs. 14-19, $\times 1,000$; Figs. 20-21, $\times 2000$. 14. Individual with bristles in position usual when swimming. 15. Cell infected by a parasite, (cf. Harris, 1953), swimming (c.=remains of chromatophores, $p_{.}=$parasite). Two short bristles present and one forward pointing long bristle. 16. Group of scales including anterior middle and tail scales. 17-19. Cysts showing variation of pore. 20. Cell with normal chromatophore, short and long bristles showing shape of anterior end of cell. 21. Cell without bristles, chromatophore divided by a string of contractile vacuoles, shows shape of the anterior end. In Figs. 20, 21 the tail is omitted.

Description of Mallomonas akrokomos as seen with the electron microscope

(Plates 3 and 4)

The scales of Mallomonas akrokomos as seen in the electron microscope are rather different from those of most other species of Mallomonas and it is not possible to apply the terms shield and flange, though a dome is present on the bristle-bearing scales. All the scales are elongated and form thin slightly convex plates of silica and all show a more or less oval patch of close perforations near their posterior end, but other details vary in scales from different parts of the cell. Only the two anterior rows have bristle-bearing domes. These scales are also distinguished by having longitudinal ribs a little inside the thickened margin, separated from the margin by a row of perforations. These scales are of two sizes, the ones next the flagellum being smaller than the succeeding ones. None of the rest of the scales have a dome, and all, including the tail scales, have a toothed anterior margin. The scales over the main part of the cell are somewhat oval, bluntly-pointed at each end and becoming narrower further from the anterior end. These scales are thickened at the 
posterior end and have a thickened posterior margin, inside which is a single row of perforations. As the cell narrows towards the tail the scales become increasingly narrow and convex and change somewhat in shape. They become rounded in front and taper towards their thickened posterior end. Usually these scales are somewhat shorter than those further forward. The last two scales form the tail; their anterior part is strongly concave and they taper to a fine point and are two or three times the length of the previous scales. Thickened ridges extend down the converging sides and join at the end. These two scales fit closely together forming an elongated tube, the upper part of which overlaps the scales next in front (Pl. 3, fig. 20; Pl. 4, fig. 23).

The bristles are similar to each other except in length. They are toothed and have a club-shaped foot which is more thickened than that found in most species. Some are nearly straight and some distinctly curved. Plate 4, fig. 21, shows the group of bristles belonging to a single cell.

\section{Discussion}

Mallomonas akrokomos has been placed by Conrad (1927) in a group by itself called 'triangulares' as distinguished by its 'triangular' scales. I think that the triangles Conrad saw were just the exposed ends of the scales. $M$. akrokomos does, however, stand by itself, for no other species has elongated scales placed longitudinally. Many species have oval scales but they are placed in oblique or transverse rows and overlap, to a greater or less extent, laterally. In $M$. akrokomos the very considerable overlap is always on the longitudinal axis. In addition, no other species has a tail made of two much elongated scales as in $M$. akrokomos. The posterior end is usually composed of smaller scales than the rest of the cell.

The chromatophore of Mallomonas akrokomos is interesting. In all the species of Mallomonas that I know the chromatophore is divided into two lobes by an anterior and posterior cleft. A contractile vacuole may sometimes be seen in the anterior cleft of some species and one or more are often seen in the posterior cleft of many species. I have never seen in any other species, what is sometimes met with in the chromatophore of $M$. akrokomos, namely, a chromatophore divided into two lobes only by a string of contractile vacuoles.

The longitudinal division of the cells described here differs from that described by Conrad (1927). He stated that the contents of the mother cell divided and that later the two daughter cells escaped from the armour of the mother cell. Conrad's type of division corresponds with that described by Carter (1937) for Mallomonas anglica, but $I$ have not yet observed it in M. akrokomos.

A number of varieties of Mallomonas akrokomos have been described. M. akrokomos var. parvula Conrad (1927) differs from the type by its considerably smaller size, 8-12 $\mu$ long $\times 2-3 \mu$ broad, and by having only four or fewer bristles. The description is perfectly clear and this is probably rightly regarded as a variety. It is possible, however, that it may be found to be only a developmental stage of $M$. akrokomos corresponding to the stage called 
'small oval' in the study of $M$. intermedia var. gesticulans (Harris, 1953). If a good sample of this variety should be found it would be interesting to follow its development.

Woloszynzka (1939) described some Polish specimens as Mallomonas akrokomos forma Tatrica. She considered that they differed from the type in having shorter and straighter bristles, up to $15 \mu$ long. In the material I examined most closely the bristles were up to $35 \mu$ long, though they were often shorter. I do not know the significance of these differences of maximum length. Considerable variation in curvature may be seen in a single individual (Pl. 4, fig. 21). Woloszynska was the first person to observe that the scales are really oval and that the bristles are usually of two lengths in one cell, though their numbers are very inconstant.

Mallomonas akrokomos is sometimes attacked by a parasite which, after penetrating the cell, usually near the rear, gradually consumes and replaces most of the chromatophore. The front of the host cell, however, remains active and apparently uninfected. The parasite forms a cyst while still inside the cell armour (Fig. 15). The parasite closely resembles that described more fully for $M$. teilingii (Harris, 1953), the spore of which had earlier been regarded as a distinct species of Mallomonas.

I should like to thank Dr D. E. Bradley of the Research Laboratory, Associated Electrical Industries, Aldermaston, Berkshire, for taking the electron micrographs, and Dr T. E. Allibone, F.R.S., Director of A.E.I. Research Laboratory, for permitting this.

\section{REFERENCES}

Asmund, B. (1956). Electron microscope observations on Mallomonas species and remarks on their occurrence in some Danish ponds. Bot. Tiddskr. 53, 75.

Bourelly, P. (1951). Une nouvelle espèce de Chrysomonadine: Mallomonas doignonii. Bull. Soc. bot. Fr. 98, 156.

Carter, N. (1937) Pseudomallomonas anglica. New Phytol. 36, 57.

Conrad, W. (1927). Essai d'une monographie des genres Mallomonas Perty et Pseudomallomonas Chodat. Arch. Protistenk, 57, 467.

Conrad, W. (1933). Revision du genre Mallomonas Perty et Pseudomallomas Chodat. Mem. Mus. Hist. nat. Belg. 56, 1-82.

Harris, K. (1953). A contribution to our knowledge of Mallomonas. J. Linn. Soc. (Bot.), 55, 88.

Harris, K. \& Bradlex, D. E. (1957). An examination of the scales and bristles of Mallomonas in the electron microscope, using carbon replicas. J. Roy. micr. Soc. 76, 37.

Huber-Pestalozzi, G. (1941). Die Binnengewässer. Das Phytoplankton der Süsswassers. 16, $(2,1)$, p. 101 Stuttgart: Schweizerbartsche Verlagsbuchshandlung.

Kisselew, J. A. (1931). Zur Morphologie einiger neuer und seltener Vertreter des pflanzlichen Microplanktons. Arch. Protistenk. 73, 239.

Krieger, W. (1930). Untersuchungen über Plankton Chrysomonaden. Bot. Arch. $29,278$.

NygaARd, G. (1949). Hydrobiological studies on some Danish ponds and lakes. Part 2. K. Danske. Vidensk. Selsk. Biol. Skrift. 7, 1.

Pascher, A. (1913). Die Süsswasser-Flora Deutschlands, Österreichs und der Schweiz. 2, 7-95, Jena: G. Fischer.

Penard, E. (1919). Mallomonas insignis spec.nov. Bull. Soc. bot. Geneve. 2ème serie, 19, 122. 
Schrluer, J. (1926). Der Thermische Einfluss und die Wirkung des Eises auf die Planktischen Herbstvegetationen in den Altwässern der Donau bei Wien. Arch. Protistenk, 56, 13.

Stokes, A. (1888). A Preliminary Contribution towards the History of Fresh Water Infusoria of the U.S.A., vol. I.

Swirenko, (1924). Deux interessants Mallomonas du plankton des eaux stagnantes. Arch. russes Protist. 111, 180 (quoted from Conrad, 1927).

Woloszynska, J. (1939). Der Algen der Tatraseen und Tumfeln. 4. Mallomonas Arten in dem Tatraseen. Acta Soc. Bot. Polon. 16, 29.

\section{EXPLANATION OF PLATES}

\section{Plate 1}

Mallomonas insignis. Replicas. $\times 6000$

Fig. 1. Inner side of anterior scale with spine, hollow at base.

Fig. 2. Outer side of anterior scale with spine.

Fig. 3. Outer side of scale from near anterior end of cell.

Fig. 4. Outer side of undisturbed scale armour from about middle of cell.

Figs. 5, 6. Outer side of scales from part of cell which narrows towards the tail.

\section{Prate 2}

Mallomonas insignis: Figs. 7, 8 and 10 direct electron micrographs; figs. 9, 11-14, replicas. All $\times 6000$, except fig. 4 , which is $\times 8000$.

Fig. 7. Anterior or near anterior scale, with small spine.

Fig. 8. Scale from near anterior end of cell.

Fig. 9. Outer side of scale from front part of tail, with short spine.

Fig. 10. Scale from middle of cell showing perforations.

Fig. 11. End of tail showing variation in bristle length and backward pointing scales.

Fig. 12. Outer side of tail scale.

Fig. 13. Inner side of tail scale showing hollow in base of spine.

Fig. 14. Inner side of scale from part of cell which narrows towards the tail (compare scale Pl. 1, fig. 5).

\section{Plate 3}

Mallomonas akrokomos. Replicas. All $\times 8000$

Fig. 15. Inside of group of anterior scales of two sizes and some bristle bases.

Fig. 16. Outside of two small anterior scales.

Fig. 17. Outer side of scale from near posterior end of cell showing regions of perforations and thickened margin (compare Pl. 4, fig. 25).

Fig. 18. Scale armour just in front of tail showing scales in longitudinal rows.

Fig. 19. Group of scales from near tail showing serrated forward margins.

Fig. 20. Tail and scales just in front of it, one tail scale facing upwards with thickened margins which meet at extreme end.

\section{Puate 4}

Mallomonas akrokomos. Direct electron micrographs. $\times 8000$.

Fig. 21. Group of eight bristles of varying length and curvature.

Fig. 22. Two anterior scales of different sizes, showing perforations.

Fig. 23. Tail, showing the two scales slightly separated and the base of scales just in front.

Fig. 24. Group of scales from different parts of the cell but all fairly near the middle.

Fig. 25. Scale from near anterior end of cell.

Fig. 26. Scale from near tail. 
Journal of General Microbiology, Vol. 19, No. 1
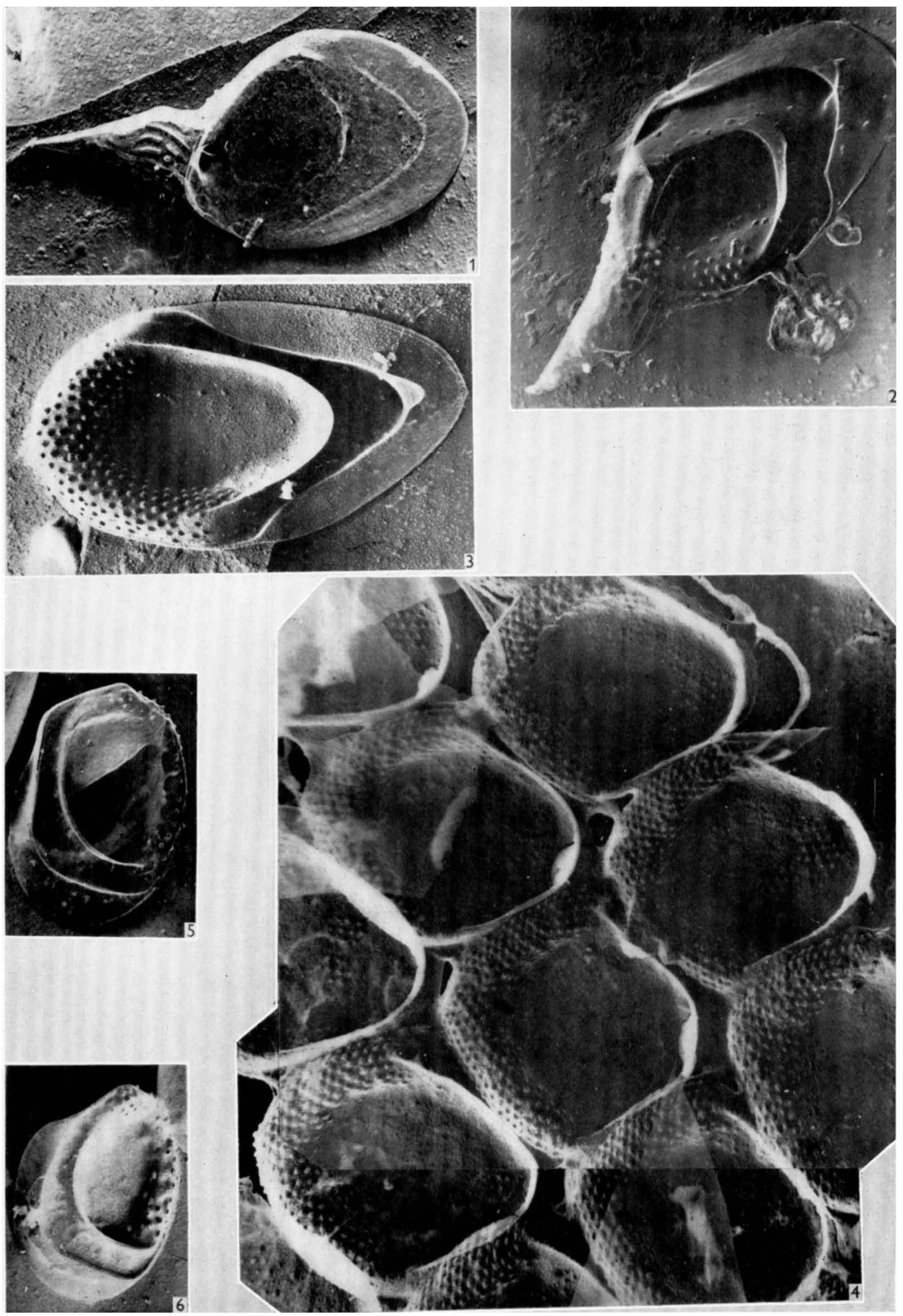

K. Harris-Electron microscopy of mallomonas. Plate 1 
Journal of General Microbiology, Vol. 19, No. 1
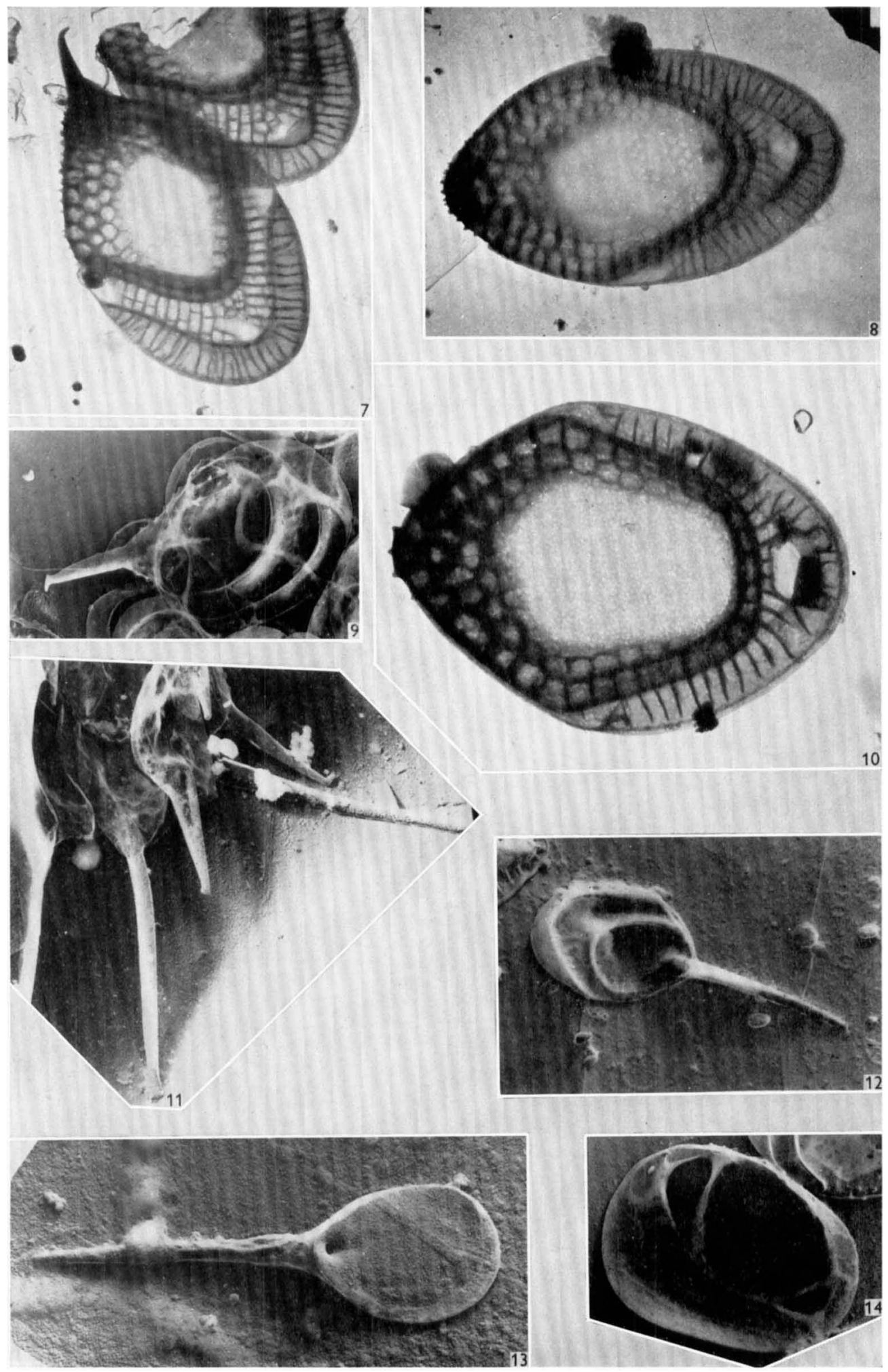

K. Harris-Electron microscopy of mallomonas. Plate 2 
Journal of General Microbiology, Vol. 19, No. 1
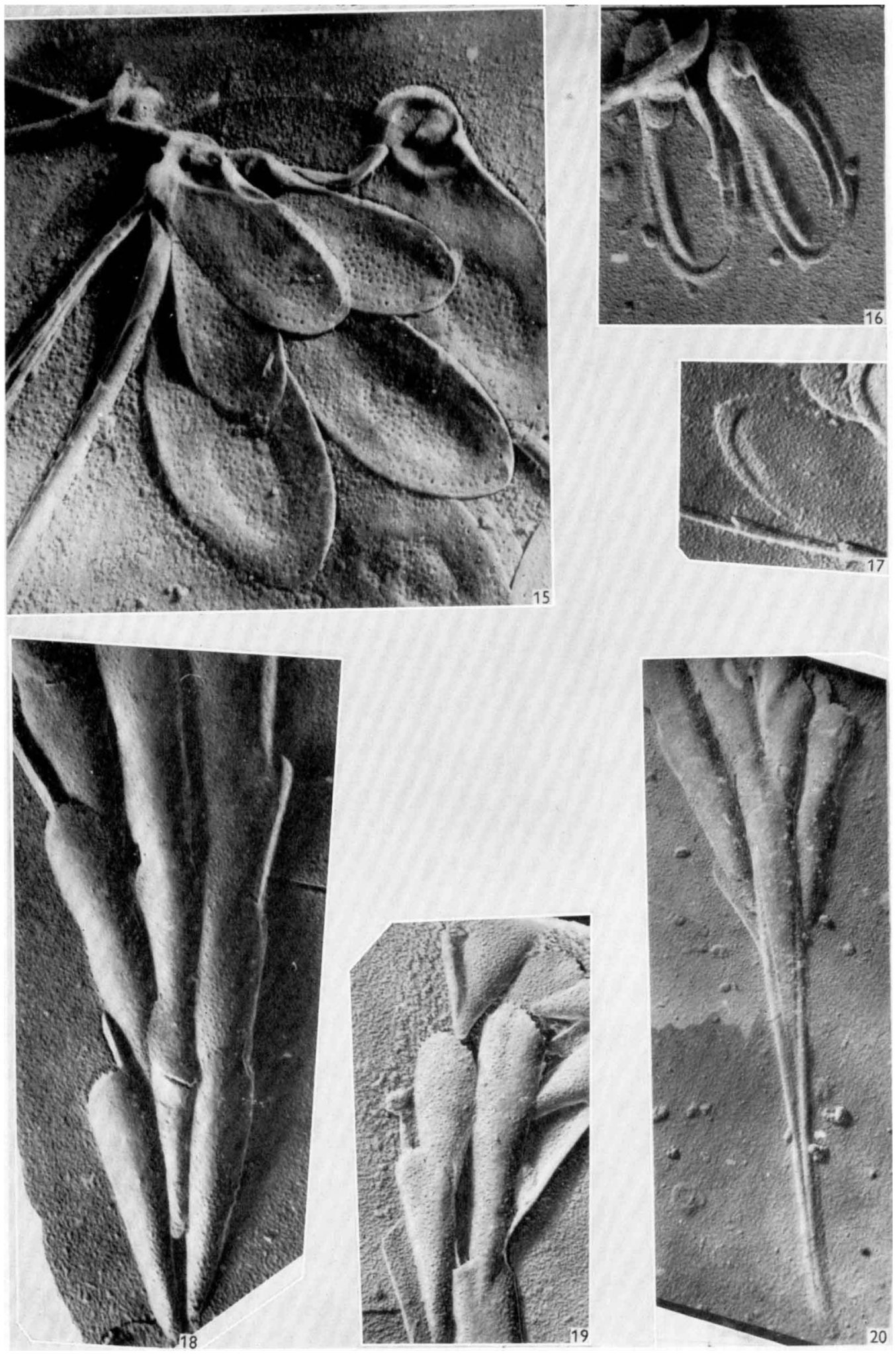

K. Harris-Electron microscopy of mallomonas. Plate 3 
Journal of General Microbiology, Vol. 19, No. 1

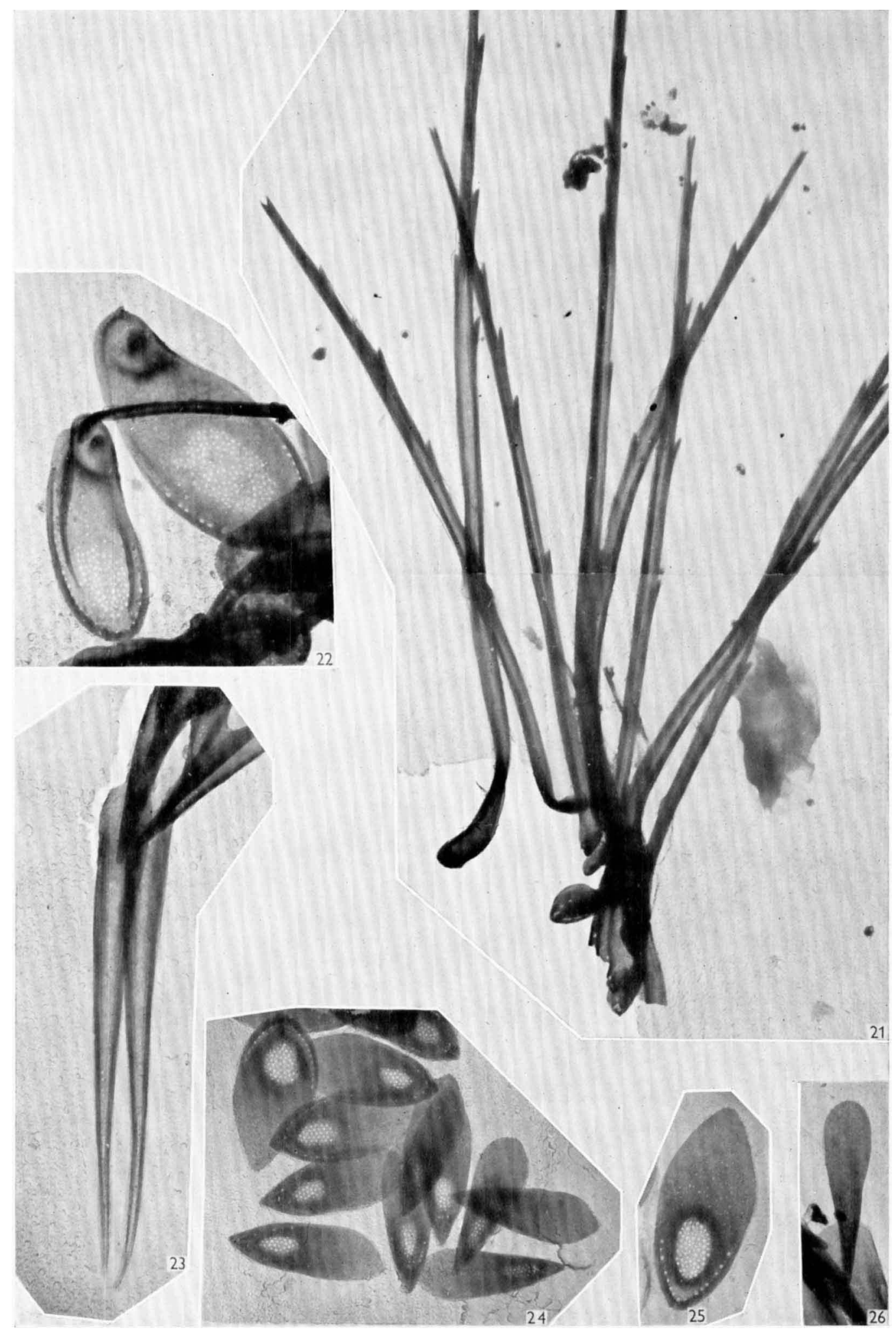

K. Harris-Electron microscopy of mallomonas. Plate 4 